\title{
Tingkat kecemasan, asupan makan, dan status gizi pada lansia di Kota Yogyakarta
}

Anxiety level, dietary intake, and nutritional status of elderly in Yogyakarta Municipality

Ninna Rohmawati ${ }^{1}$, Ahmad Husein Asdie ${ }^{2}$, Susetyowati ${ }^{3}$

${ }^{1}$ Fakultas Kesehatan Universitas Jember

${ }^{2}$ Bagian Ilmu Penyakit Dalam, Rumah Sakit Umum Pusat Dr. Sardjito

${ }^{3}$ Departemen Gizi Kesehatan, Fakultas Kedokteran Universitas Gadjah Mada

\begin{abstract}
Background: Psychological factors such as anxiety have significant contributions in determining dietary intake and nutritional status of elderly. Prevalence of malnutrition in elderly have achieved significant level. Objective: To determine correlation between anxiety level with dietary intake and nutritional status of elderly in Yogyakarta municipality. Method: This research was observational with cross sectional design. Subjects were elderly in Yogyakarta municipality who fulfilled inclusion criteria. Research subjects consisted of 214 people. Anxiety level was measured with trait-manifest anxiety scale (T-MAS) form, dietary intake with semi quantitative food frequency questionnaire (SQFFQ) method, and nutritional status was determined based on body mass armspan (BMA). Data were analyzed with chi square test and multiple logistic regression. Results: A percentage of $26.2 \%$ subjects had moderate anxiety level. Most dominant factors that influenced anxiety level was sex (OR=3.37). Bivariate analysis showed significant correlation between anxiety level and nutritional status $(p<0.05)$, subjects with moderate anxiety level were more likely to have higher nutritional status $(O R=3.54)$ and lower nutritional status $(O R=2.29)$. Significant correlation was found between moderate anxiety level with excessive dietary intake $(p<0.001 ;$ OR=6.22). Significant correlation was also found between dietary intake with nutritional status $(p<0.05)$, subjects with excessive dietary intake were more likely to have higher nutritional status $(O R=6.15)$. Conclusions: Significant correlation was found between anxiety level and nutritional status. Significant correlation was also found between anxiety level and dietary intake, and significant correlation was found between dietary intake and nutritional status.
\end{abstract}

KEY WORDS: anxiety level; dietary intake; elderly; nutritional status

\section{ABSTRAK}

Latar belakang: Faktor psikologis seperti kecemasan mempunyai kontribusi yang besar dalam menentukan asupan makan dan status gizi lansia. Prevalensi malnutrisi pada lansia telah mencapai level yang signifikan. Tujuan: Mengetahui hubungan antara tingkat kecemasan dengan asupan makan dan status gizi lansia di kota Yogyakarta. Metode: Penelitian observasional dengan rancangan cross-sectional yang dilakukan terhadap lansia di kota Yogyakarta yang memenuhi kriteria inklusi. Subyek penelitian berjumlah 214 orang. Tingkat kecemasan diukur dengan form trait-manifest anxiety scale (T-MAS), asupan makan dengan metode semi quantitative food frequency questionnaire (SQ-FFQ), dan status gizi ditentukan berdasarkan body mass armspan (BMA). Data dianalisis dengan uji Chi-Square dan regresi logistik ganda. Hasil: Sejumlah 26,2\% subjek mengalami tingkat kecemasan sedang. Faktor yang paling dominan mempengaruhi tingkat kecemasan adalah jenis kelamin $(\mathrm{OR}=3,37)$. Hasil uji bivariat menunjukkan adanya hubungan yang bermakna antara tingkat kecemasan dengan status gizi $(p<0,05)$, subjek dengan tingkat kecemasan sedang cenderung memiliki status gizi lebih $(\mathrm{OR}=3,54)$ dan status gizi kurang $(\mathrm{OR}=2,29)$. Ada hubungan yang bermakna antara tingkat kecemasan sedang dengan asupan makan lebih $(\mathrm{p}<0,001 ; \mathrm{OR}=6,22)$. Ada hubungan yang bermakna antara asupan makan dengan status gizi $(\mathrm{p}<0,05)$, subjek dengan asupan makan lebih cenderung memiliki status gizi lebih $(\mathrm{OR}=6,15)$. Simpulan: Ada hubungan yang bermakna antara tingkat kecemasan dengan status gizi dan asupan makan pada lansia, demikian juga ada hubungan yang bermakna antara asupan makan dengan status gizi lansia.

KATA KUNCI: tingkat kecemasan; asupan makan; lansia; status gizi

Korespondensi: Ninna Rohmawati, Fakultas Kesehatan Universitas Jember, Jl. Kalimantan I/93, Kampus Tegal Boto, Jember, Jawa Timur, e-mail: ninna_rohmawati@yahoo.com 


\section{PENDAHULUAN}

Peningkatan usia harapan hidup merupakan salah satu dampak dari perbaikan kualitas kesehatan dan kondisi sosial masyarakat dan tercermin dari semakin meningkatnya jumlah penduduk lanjut usia (lansia) dari tahun ke tahun. Pada tahun 2005 jumlah penduduk lansia sekitar 16,81 juta orang, meningkat pada tahun 2007 menjadi sekitar 18,96 juta orang, dan pada tahun 2009 meningkat lagi menjadi sekitar 19,32 juta orang. Angka tahun 2009 ini adalah sekitar 8,37\% dari seluruh penduduk Indonesia. Indonesia sudah mulai masuk ke kelompok negara berstruktur tua (ageing population) karena persentase penduduk lansia telah mencapai angka diatas 7\% (1).

Daerah Istimewa Yogyakarta (DIY) adalah provinsi dengan persentase penduduk lansia terbesar di Indonesia, yaitu sebesar 14,02\% (1). Laju pertumbuhan di DIY merupakan salah satu yang terkecil di Indonesia. Hal ini dapat diartikan sebagai keberhasilan program kependudukan dan pergeseran prinsip dari masalah kuantitas menuju kualitas. Usia harapan hidup (UHH) provinsi DIY merupakan yang tertinggi di Indonesia (2). Angka kesakitan penduduk lansia tahun 2009 sebesar $30,46 \%$ yang artinya bahwa dari setiap 100 orang lansia, terdapat sekitar 30 orang diantaranya mengalami sakit. Angka kesakitan penduduk lansia perkotaan (27,2\%) lebih rendah dibandingkan lansia pedesaan (32,96\%). Hal ini menunjukkan bahwa derajat kesehatan penduduk lansia di perkotaan cenderung lebih baik dibandingkan derajat kesehatan penduduk lansia di pedesaan (1). Kota Yogyakarta adalah salah satu kabupaten/kota di Provinsi Daerah Istimewa Yogyakarta. Kota Yogyakarta memiliki 14 kecamatan dengan 45 kelurahan/desa yang semuanya termasuk kota/urban (3). Jumlah penduduk usia 6074 tahun di kota Yogyakarta saat ini mencapai 33.466 orang (7,3\% dari total penduduk) dan jumlah penduduk usia $\geq 60$ tahun sebesar 42.102 orang $(9,1 \%$ dari total penduduk) (4).

Seiring dengan populasi lansia di Indonesia yang semakin meningkat, berbagai masalah kesehatan dan penyakit yang khas terdapat pada lansia akan meningkat (5). Peningkatan jumlah lansia memengaruhi aspek kehidupan mereka, antara lain perubahan-perubahan fisik, biologis, psikologis, sosial, dan munculnya penyakit degeneratif akibat proses penuaan tersebut (6). Perubahan fisik (khususnya organ perasa) merupakan salah satu faktor yang dapat memengaruhi perubahan mental lansia. Apabila seseorang bertambah tua, kemampuan fisik/ mentalnya pun perlahan tapi pasti menurun. Berbagai masalah yang muncul akibat meningkatnya populasi lansia memerlukan tindakan penanganan yang bersifat komprehensif dari berbagai pihak (7).

Data statistik badan kesehatan dunia (WHO) menyebutkan bahwa kecemasan meningkat sebesar 2,5\% setiap tahunnya dengan perbandingan $2,43 \%$ pada wanita dan $0,07 \%$ pada laki-laki. Prevalensi kecemasan lansia sebesar 34,92\% (8). Prevalensi ansietas umum pada pasien yang berusia lebih dari 65 tahun di komunitas adalah 4\% (9). Prevalensi kecemasan lansia di Finlandia sebesar 24\% (10). Kecemasan pada lansia mendapat perhatian yang sedikit jika dibandingkan dengan gangguan suasana hati (mood), gangguan kognitif, dan gangguan psikotik (11). Sedikit sekali penelitian-penelitian tindak lanjut jangka panjang tentang keadaan kecemasan jika dibandingkan dengan gangguan-gangguan depresi (12). Pada lansia, kecemasan yang patologis sedangkan pada rentang usia lain normal. Adanya faktor psikologis seperti depresi, kecemasan, dan demensia mempunyai kontribusi yang besar dalam menentukan asupan makan dan zat gizi (13).

Pemilihan makanan adalah perilaku yang multidimensi, dipengaruhi oleh berbagai faktor, termasuk parameter psikologis. Namun, masih sedikit diketahui hubungan antara parameter psikologis, seperti kecemasan dan depresi. Kecemasan merupakan salah satu faktor psikologis yang telah mendapat perhatian khusus selama beberapa dekade terakhir karena tingkat prevalensinya yang tinggi dan hubungannya dengan gangguan kronik, terutama penyakit jantung koroner $(\mathrm{RR}=2,41)(14)$, kematian jantung (cardiac death) $(\mathrm{HR}=1,48 ; \mathrm{p}=0,003)$ (15), hipertensi (16), dan diabetes mellitus (17). Beberapa faktor risiko terjadinya penyakit jantung koroner antara lain kegemukan, stres, usia, keturunan, merokok, konsumsi kolesterol berlebihan, hipertensi, dan diabetes mellitus (18).

Lebih lanjut, prevalensi malnutrisi pada lansia telah mencapai level yang signifikan yaitu sebesar 1765\% (19). Penelitian terhadap lansia di Kota Padang menyatakan bahwa sekitar $25,9 \%$ berada pada status gizi 
kurang (20). Penelitian di Denpasar juga menunjukkan setengah sampel mengalami permasalahan dalam status gizi, yaitu lansia mengalami status gizi lebih sebesar 14,64\%; status gizi normal 43,9\%; dan status gizi kurang $41,46 \%$ (21). Berdasarkan latar belakang tersebut, penelitian ini dilaksanakan dengan tujuan untuk mengetahui hubungan tingkat kecemasan dengan asupan makan dan status gizi pada lansia di Kota Yogyakarta.

\section{BAHAN DAN METODE}

Jenis penelitian ini adalah penelitian observasional dengan rancangan cross sectional. Penelitian dilakukan di kota Yogyakarta, pada bulan November 2011 Januari 2012. Populasi penelitian adalah seluruh lansia di kota Yogyakarta. Berdasarkan hasil perhitungan sampel diperoleh jumlah sampel minimal yang harus dipenuhi adalah 214 orang. Perhitungan besar sampel menggunakan rumus pengujian hipotesis untuk dua proporsi populasi (22) dengan nilai kepercayaan $95 \%$; kekuatan uji penelitian (power of the test) sebesar $80 \%$; proporsi asupan kurang pada lansia depresi sebesar 0,47 ; dan proporsi asupan kurang pada lansia tidak depresi sebesar 0,32 . Pengambilan sampel dilakukan dengan metode multistage random sampling.

Sampel penelitian diambil dari 5 kecamatan yaitu Mantrijeron, Umbulharjo, Gondomanan, Wirobrajan, dan Jetis melalui kegiatan posyandu lansia yang ada di wilayah tersebut. Kriteria inklusi yang digunakan adalah berusia $\geq 60$ tahun, masih bisa berkomunikasi dengan baik, dan terdaftar atau tercatat sebagai warga di wilayah penelitian. Kriteria eksklusinya adalah lansia yang mengalami penurunan daya ingat (gangguan penurunan kognitif dinilai dengan kuesioner MMSE), lansia yang menderita penyakit kronis yang membutuhkan diit khusus, ketidakmampuan merentangkan lengan dengan sempurna, dan lansia yang sedang mengonsumsi obat anti cemas. Variabel bebas dalam penelitian ini adalah tingkat kecemasan, variabel tergantung yaitu status gizi, dan variabel antara adalah asupan makan. Selain itu, terdapat variabel yang berpotensi sebagai pengganggu yang turut diperhitungkan dalam penelitian ini yaitu umur, jenis kelamin, pendidikan, status pekerjaan, pendapatan, status domisili, dan aktivitas olahraga.
Tingkat kecemasan diukur dengan menggunakan form trait-manifest anxiety scale (T-MAS) yang berisi 50 pertanyaan, jawaban "YA" diberi skor 1 dan jawaban "TIDAK" diberi skor 0 yang disusun oleh Janet Taylor. Skor T-MAS kurang dari 20 dinyatakan tingkat kecemasan ringan, skor T-MAS antara 20 sampai dengan 40 dinyatakan tingkat kecemasan sedang, sementara skor T-MAS lebih dari 40 dinyatakan tingkat kecemasan berat. Instrumen T-MAS memiliki validitas dan reliabilitas yang cukup tinggi yaitu sebagai berikut: sensitivitas $90 \%$; spesifisitas $90,4 \%$; nilai ramal positif $94,7 \%$; nilai ramal negatif $99,4 \%$; efektifitas $92,5 \%$; dan reliabilitas menurut DSM-III-R dengan metode analisis R 20 didapatkan hasil $\mathrm{r}=0,86$, yang berarti konsistensi internal alat ukur tersebut baik atau reliabel.

Asupan makan diukur dengan semi quantitative food frequency questionnaire ( $S Q-F F Q$ ) yang meliputi asupan energi, protein, lemak, dan karbohidrat yang dikonsumsi dalam waktu 3 bulan terakhir. Hasil estimasi asupan makan tersebut dibandingkan dengan nilai angka kecukupan gizi (AKG) rata-rata orang Indonesia yang disesuaikan menurut kelompok umur (6). Pada tahap awal, SQ-FFQ disusun dengan memasukkan jenis-jenis makanan yang diperkirakan lazim dikonsumsi masyarakat setempat. Pada tahap ini, jumlah makanan yang masuk ke dalam daftar adalah sebanyak 135 jenis. Selanjutnya, dilakukan uji coba SQ-FFQ tersebut terhadap 20 orang lansia yang berasal dari wilayah dengan karakteristik makanan yang serupa untuk memperoleh informasi mengenai daftar makanan yang benar-benar lazim dikonsumsi. Uji coba tersebut memberikan hasil bahwa dari 135 jenis makanan yang tercantum dalam daftar, terdapat 103 jenis makanan yang lazim dikonsumsi oleh sebagian besar subJek uji coba. Oleh karena itu, yang digunakan sebagai instrumen penelitian adalah SQ-FFQ dengan 103 jenis makanan.

Pada saat pengambilan data asupan makan, subjek diminta untuk menjelaskan seberapa sering mengonsumsi setiap jenis makanan yang tercantum dalam kuesioner selama 3 bulan terakhir dengan kemungkinan jawaban yaitu berapa kali per hari, berapa kali per minggu, berapa kali per bulan, atau berapa kali per 3 bulan. Perhitungan asupan makan subjek dilakukan dengan cara mengalikan frekuensi konsumsi yang dilaporkan oleh subjek untuk 
setiap jenis makanan dengan besar porsi setiap kali makan (dalam gram), kemudian hasilnya dikalikan dengan kandungan zat gizi (energi, protein, lemak, karbohidrat) dalam setiap jenis makanan tersebut. Langkah terakhir adalah menjumlahkan kontribusi zat-zat gizi tersebut dari semua jenis makanan yang tercantum dalam kuesioner sehingga diperoleh rata-rata asupan makan subjek dalam 3 bulan terakhir. Pengambilan data asupan makan menggunakan bantuan food model.

Data status gizi diperoleh dengan menentukan body mass armspan (BMA) yaitu dengan cara membandingkan berat badan (dalam $\mathrm{kg}$ ) dan rentang lengan (dalam meter ${ }^{2}$ ) kemudian dibedakan menjadi 3 kategori yaitu status gizi lebih (BMA perempuan $>22,8$; laki-laki $>25,1$ ); status gizi baik (BMA perempuan 18,7-22,8; laki-laki 20,1-25); dan status gizi kurang (BMA perempuan $<18,7$; laki-laki $<20,1)$. Berat badan diukur menggunakan timbangan injak dengan ketelitian 0,1 kg sedangkan rentang lengan diukur menggunakan pita meteran dengan ketelitian 0,1 $\mathrm{cm}(23)$.

Data umur (60-74 tahun dan $\geq 75$ tahun); jenis kelamin; pendidikan (tamat SD/SMP/SMA dan tamat PT); status pekerjaan; pendapatan $(<\mathrm{Rp} .808 .000,00$ dan $\geq$ Rp.808.000,00); status domisili (tinggal sendiri dan tinggal bersama keluarga); dan aktivitas olahraga (tidak teratur $\leq 2 \mathrm{x} /$ minggu dan olahraga teratur $\geq 3 \mathrm{x}$ / minggu) diperoleh melalui kuesioner yang ditanyakan kepada subjek. Pengumpulan data dilakukan oleh peneliti dengan bantuan 5 orang enumerator yang telah diberikan pengarahan dan pelatihan sebelumnya. Data tersebut selanjutnya diuji secara statistik dengan derajat kemaknaan 95\% dan $\mathrm{p}<0,05$ menggunakan uji ChiSquare dan uji regresi logistik ganda.

\section{HASIL}

Subjek penelitian berjumlah 214 orang yang tinggal di Kecamatan Mantrijeron, Umbulharjo, Gondomanan, Wirobrajan, dan Jetis. Sebagian besar subjek berusia 60-74 tahun $(85,1 \%)$; berjenis kelamin perempuan (81,3\%); memiliki pendidikan terakhir tamat SMP/ SMA (47,2\%); tidak bekerja (pensiunan/rumah tangga) $(74,3 \%)$; dan pendapatan rata-rata subjek sebagian besar (56,1\%) kurang dari Rp.808.000,00 per bulan.
Tabel 1. Distribusi frekuensi karakteristik subjek penelitian

\begin{tabular}{lcc}
\hline \multicolumn{1}{c}{ Variabel } & n & \% \\
\hline Umur (tahun) & 182 & 85,1 \\
$\quad 60-74$ & 32 & 14,9 \\
$\quad$ 75 & & \\
Jenis kelamin & 174 & 81,3 \\
$\quad$ Perempuan & 40 & 18,7 \\
$\quad$ Laki-laki & & \\
Agama & 194 & 90,6 \\
$\quad$ Islam & 20 & 9,4 \\
$\quad$ Katolik/Protestan & & \\
Pendidikan terakhir & 84 & 39,3 \\
$\quad$ Tamat SD & 101 & 47,2 \\
$\quad$ Tamat SMP/SMA & 29 & 13,5 \\
$\quad$ Tamat PT & & \\
Status pekerjaan & 1 & 0,5 \\
$\quad$ Petani & 54 & 25,2 \\
$\quad$ Wiraswasta/pedagang/jasa & 54,3 \\
$\quad$ Pensiunan/tidak bekerja & 159 & 74,3 \\
Penghasilan rata-rata per bulan & & \\
$\quad<$ Rp. 808.000,00 & 120 & 56,1 \\
$\quad$ R Rp. 808.000,00 & 94 & 43,9 \\
Status domisili & & \\
$\quad$ Tinggal sendiri & 18 & 8,4 \\
$\quad$ Tinggal bersama keluarga & 196 & 91,6 \\
Aktivitas olahraga & & \\
$\quad$ Tidak teratur & 87 & 40,6 \\
$\quad$ Teratur & 127 & 59,4 \\
\hline
\end{tabular}

Tabel 2. Analisis regresi logistik ganda (variabel terikat: tingkat kecemasan)

\begin{tabular}{|c|c|c|c|c|}
\hline \multirow{2}{*}{ Variabel } & \multirow{2}{*}{ OR } & \multirow{2}{*}{$\mathbf{p}$} & \multicolumn{2}{|c|}{$95 \% \mathrm{CI}$} \\
\hline & & & Lower & Upper \\
\hline Jenis kelamin & & & & \\
\hline $\begin{array}{l}\text { Perempuan } \\
\text { Laki-laki }\end{array}$ & 3,37 & 0,030 & 1,125 & 10,117 \\
\hline Pendidikan & & & & \\
\hline $\begin{array}{l}\text { Tamat PT } \\
\text { Tamat SD/SMP/SMA }\end{array}$ & 1,39 & 0,538 & 0,487 & 3,971 \\
\hline Status Domisili & & & & \\
\hline $\begin{array}{l}\text { Tinggal bersama } \\
\text { keluarga } \\
\text { Tinggal sendiri }\end{array}$ & 1,67 & 0,322 & 0,602 & 4,683 \\
\hline Aktivitas olahraga & & & & \\
\hline $\begin{array}{l}\text { Tidak teratur } \\
\text { Teratur }\end{array}$ & 1,75 & 0,082 & 0,932 & 3,287 \\
\hline Log likelihood & & 821 & & \\
\hline $\mathrm{R}^{2}$ & & & & \\
\hline
\end{tabular}

Sebagian besar subjek tinggal bersama keluarga (91,6\%) dan sebagian besar subjek $(59,4 \%)$ teratur melakukan olahraga (Tabel 1). 
Tabel 3. Hubungan antara tingkat kecemasan dengan status gizi

\begin{tabular}{|c|c|c|c|c|c|}
\hline \multirow{2}{*}{$\begin{array}{c}\text { Tingkat } \\
\text { kecemasan }\end{array}$} & \multicolumn{3}{|c|}{ Status gizi } & \multirow[b]{2}{*}{$\mathbf{p}$} & \multirow[b]{2}{*}{ OR (CI) } \\
\hline & $\begin{array}{l}\text { Lebih } \\
\text { n (\%) }\end{array}$ & $\begin{array}{c}\text { Kurang } \\
\text { n (\%) }\end{array}$ & $\begin{array}{c}\text { Baik } \\
\text { n (\%) }\end{array}$ & & \\
\hline Sedang & $44(78,6)$ & $7(12,5)$ & $5(8,9)$ & $0,000^{\mathrm{a}}$ & $3,54(2,58-4,84)^{\mathrm{a}}$ \\
\hline Ringan & $32(20,3)$ & $32(20,3)$ & $94(59,4)$ & $0,015^{\mathrm{b}}$ & $2,29(1,31-4,04)^{b}$ \\
\hline
\end{tabular}

a tingkat kecemasan sedang dan ringan dengan status gizi lebih dan baik;

${ }^{\mathrm{b}}$ tingkat kecemasan sedang dan ringan dengan status gizi kurang dan baik; (referensi: tingkat kecemasan ringan dan asupan energi cukup)

Tabel 4. Hubungan antara tingkat kecemasan dengan asupan makan

\begin{tabular}{|c|c|c|c|c|c|}
\hline \multirow{2}{*}{$\begin{array}{c}\text { Tingkat } \\
\text { kecemasan }\end{array}$} & \multicolumn{3}{|c|}{ Asupan energi } & \multirow[b]{2}{*}{$\mathbf{p}$} & \multirow{2}{*}{ OR (CI) } \\
\hline & $\begin{array}{l}\text { Lebih } \\
\text { n (\%) }\end{array}$ & $\begin{array}{c}\text { Kurang } \\
\text { n (\%) }\end{array}$ & $\begin{array}{l}\text { Cukup } \\
\text { n (\%) }\end{array}$ & & \\
\hline Sedang & $42(75,0)$ & $6(10,7)$ & $8(14,3)$ & $0,000^{\mathrm{a}}$ & $6,22(3,82-10,1)^{a}$ \\
\hline \multirow[t]{2}{*}{ Ringan } & $15(9,5)$ & $47(29,7)$ & $96(60,8)$ & $0,451^{\mathrm{b}}$ & $1,31(0,68-2,49)^{\mathrm{b}}$ \\
\hline & \multicolumn{3}{|c|}{ Asupan protein } & & \\
\hline Sedang & $42(75,0)$ & $5(8,9)$ & $9(16,1)$ & $0,000^{\mathrm{a}}$ & $2,68(1,98-3,63)^{a}$ \\
\hline \multirow[t]{2}{*}{ Ringan } & $35(22,2)$ & $44(27,8)$ & $79(50,0)$ & $0,996^{\mathrm{b}}$ & $0,99(0,47-2,09)^{\mathrm{b}}$ \\
\hline & \multicolumn{3}{|c|}{ Asupan lemak } & & \\
\hline Sedang & $46(82,2)$ & $5(8,9)$ & $5(8,9)$ & $0,000^{\mathrm{a}}$ & $3,57(2,56-4,98)^{a}$ \\
\hline \multirow[t]{2}{*}{ Ringan } & $28(17,7)$ & $47(29,8)$ & $83(52,5)$ & $0,383^{b}$ & $1,38(0,71-2,67)^{b}$ \\
\hline & \multicolumn{3}{|c|}{ Asupan karbohidrat } & & \\
\hline Sedang & $42(75,0)$ & $6(10,7)$ & $8(14,3)$ & $0,000^{\mathrm{a}}$ & $4,45(2,94-6,73)^{a}$ \\
\hline Ringan & $20(12,7)$ & $52(32,9)$ & $86(54,4)$ & $0,704^{b}$ & $1,14(0,59-2,16)^{b}$ \\
\hline
\end{tabular}

a tingkat kecemasan sedang dan ringan dengan status gizi lebih dan baik;

${ }^{\mathrm{b}}$ tingkat kecemasan sedang dan ringan dengan status gizi kurang dan baik; (referensi: tingkat kecemasan ringan dan asupan energi cukup)

Hasil pengukuran tingkat kecemasan menunjukkan bahwa sebagian besar subjek $(73,8 \%)$ memiliki tingkat kecemasan ringan dan sebesar 26,2\% memiliki tingkat kecemasan sedang. Hasil analisis regresi logistik ganda menunjukkan bahwa jenis kelamin merupakan faktor yang dominan berhubungan dengan tingkat kecemasan $(\mathrm{OR}=3,37)$ (Tabel 2).

Sebagian besar subjek memiliki status gizi baik (46,3\%). Subjek dengan status gizi lebih sebesar 35,5\% (76 orang) dan subjek dengan status gizi kurang sebesar 18,2\% (39 orang). Hasil uji statistik menunjukkan bahwa terdapat hubungan yang signifikan antara tingkat kecemasan dengan status gizi subyek $(\mathrm{p}<0,05)$. Odds Ratio (OR) sebesar 3,54 menunjukkan bahwa subjek yang mengalami tingkat kecemasan sedang memiliki kemungkinan 3,54 kali lebih besar untuk mengalami status gizi lebih dibandingkan dengan subjek yang mengalami tingkat kecemasan ringan. Odds Ratio (OR) sebesar 2,29 menunjukkan bahwa subjek yang mengalami tingkat kecemasan sedang memiliki kemungkinan 2,29 kali lebih besar mengalami status gizi kurang dibandingkan dengan subjek yang mengalami tingkat kecemasan ringan. Sebagian besar subjek yang mengalami tingkat kecemasan sedang memiliki status gizi lebih (78,6\%) (Tabel 3)

Hasil uji Chi-Square antara tingkat kecemasan dengan asupan makan menunjukkan bahwa ada hubungan yang bermakna secara statistik antara tingkat kecemasan sedang dengan asupan makan lebih $(\mathrm{p}<0,001)$, tetapi tidak ada hubungan yang bermakna secara statistik antara tingkat kecemasan sedang dengan asupan makan kurang ( $p>0,05)$ (Tabel 4). Pada kelompok subjek dengan tingkat kecemasan sedang, asupan energi, protein, lemak, dan karbohidrat sebagian besar subjek berada pada kategori asupan lebih. Sementara itu, hasil uji Chi Square menunjukkan bahwa asupan makan yang meliputi asupan energi, protein, lemak, dan karbohidrat memiliki hubungan yang signifikan dengan status gizi $(p<0,05)$ (Tabel 5). 
Ninna Rohmawati, dkk: Tingkat kecemasan, asupan makan, dan status gizi pada lansia di Kota Yogyakarta

Tabel 5. Hubungan antara asupan makan dengan status gizi

\begin{tabular}{|c|c|c|c|c|c|}
\hline \multirow[b]{2}{*}{ Asupan makan } & \multicolumn{3}{|c|}{ Status gizi } & \multirow[b]{2}{*}{$\mathbf{p}$} & \multirow[b]{2}{*}{ OR (CI) } \\
\hline & $\begin{array}{l}\text { Lebih } \\
\text { n (\%) }\end{array}$ & $\begin{array}{c}\text { Kurang } \\
\text { n (\%) }\end{array}$ & $\begin{array}{c}\text { Baik } \\
\text { n (\%) }\end{array}$ & & \\
\hline Energi & & & & $0,0000^{\mathrm{a}}$ & $6,15(3,7-10,3)^{a}$ \\
\hline Lebih & $47(82,4)$ & $3(5,3)$ & $7(12,3)$ & $0,0000^{\mathrm{b}}$ & $3,91(2,1-7,1)^{\mathrm{b}}$ \\
\hline Kurang & $16(30,2)$ & $24(45,3)$ & $13(24,5)$ & $0,0458^{\mathrm{c}}$ & $2,27(1,7-6,7)^{\mathrm{c}}$ \\
\hline Cukup & $13(12,5)$ & $12(11,6)$ & $79(75,9)$ & $0,0000^{\mathrm{d}}$ & $4,92(2,7-8,7)^{\mathrm{d}}$ \\
\hline Protein & & & & $0,0000^{\mathrm{a}}$ & $5,27(3,0-9,3)^{\mathrm{a}}$ \\
\hline Lebih & $52(67,5)$ & $8(10,4)$ & $17(22,1)$ & $0,0008^{\mathrm{b}}$ & $3,14(1,6-6,2)^{b}$ \\
\hline Kurang & $13(26,5)$ & $20(40,8)$ & $16(32,7)$ & $0,0481^{\mathrm{c}}$ & $2,24(1,0-4,9)^{\mathrm{c}}$ \\
\hline Cukup & $11(12,5)$ & $11(12,5)$ & $66(75,0)$ & $0,0000^{\mathrm{d}}$ & $3,88(2,1-7,2)^{\mathrm{d}}$ \\
\hline Lemak & & & & $0,0000^{\mathrm{a}}$ & $5,75(3,3-10,1)^{\mathrm{a}}$ \\
\hline Lebih & $50(67,6)$ & $10(13,5)$ & $14(18,9)$ & $0,0001^{\mathrm{b}}$ & $3,68(1,9-7,1)^{b}$ \\
\hline Kurang & $15(28,9)$ & $22(42,3)$ & $15(28,8)$ & $0,0002^{\mathrm{c}}$ & $4,58(1,9-10,7)^{\mathrm{c}}$ \\
\hline Cukup & $11(12,5)$ & $7(7,9)$ & $70(79,6)$ & $0,0000^{\mathrm{d}}$ & $6,54(3,1-13,9)^{\mathrm{d}}$ \\
\hline Karbohidrat & & & & $0,0000^{\mathrm{a}}$ & $5,98(3,5-10,2)^{\mathrm{a}}$ \\
\hline Lebih & $49(79,1)$ & $4(6,5)$ & $9(14,5)$ & $0,0002^{\mathrm{b}}$ & $3,32(1,7-6,3)^{b}$ \\
\hline Kurang & $15(25,9)$ & $26(44,8)$ & $17(29,3)$ & $0,0499^{c}$ & $2,81(1,1-7,8)^{\mathrm{c}}$ \\
\hline Cukup & $12(12,7)$ & $9(9,6)$ & $73(77,7)$ & $0,0000^{\mathrm{d}}$ & $5,51(2,8-10,7)^{\mathrm{d}}$ \\
\hline
\end{tabular}

a Asupan makan lebih dan cukup dengan status gizi lebih dan baik; ${ }^{\mathrm{b}}$ Asupan makan kurang dan cukup dengan status gizi lebih dan baik; ' Asupan makan lebih dan cukup dengan status gizi kurang dan baik; ${ }^{\mathrm{c}}$ Asupan makan kurang dan cukup dengan status gizi kurang dan bai; (referensi: asupan makan cukup dan status gizi baik)

Tabel 6. Analisis regresi logistik (variabel terikat: status gizi)

\begin{tabular}{|c|c|c|c|c|c|c|c|c|c|c|}
\hline \multirow{2}{*}{ Variabel } & \multicolumn{2}{|c|}{ Model 1} & \multicolumn{2}{|c|}{ Model 2} & \multicolumn{2}{|c|}{ Model 3} & \multicolumn{2}{|c|}{ Model 4} & \multicolumn{2}{|c|}{ Model 5} \\
\hline & OR (CI) & $\mathbf{p}$ & OR (CI) & $\mathbf{p}$ & OR (CI) & $\mathbf{p}$ & OR (CI) & $\mathbf{p}$ & OR (CI) & $\mathbf{p}$ \\
\hline Tingkat kecemasan & $\begin{array}{c}6,68 \\
(2,2-20,5) \\
\end{array}$ & 0,001 & $\begin{array}{c}7,04 \\
(2,3-21,4) \\
\end{array}$ & 0,001 & $\begin{array}{c}6,94 \\
(2,3-20,7) \\
\end{array}$ & 0,001 & $\begin{array}{c}7,62 \\
(2,6-22,4) \\
\end{array}$ & 0,000 & $\begin{array}{c}6,93 \\
(2,3-18,8) \\
\end{array}$ & 0,001 \\
\hline $\begin{array}{l}\text { Asupan } \\
\text { energi }\end{array}$ & $\begin{array}{c}1,84 \\
(0,6-5,4)\end{array}$ & 0,269 & - & - & - & - & - & - & - & - \\
\hline $\begin{array}{l}\text { Asupan } \\
\text { protein }\end{array}$ & $\begin{array}{c}2,02 \\
(0,8-4,9) \\
\end{array}$ & 0,125 & $\begin{array}{c}2,14 \\
(0,8-5,2)\end{array}$ & 0,094 & - & - & - & - & - & - \\
\hline $\begin{array}{l}\text { Asupan } \\
\text { lemak }\end{array}$ & $\begin{array}{c}2,69 \\
(0,9-7,4)\end{array}$ & 0,055 & $\begin{array}{c}3,42 \\
(1,4-8,6)\end{array}$ & 0,009 & $\begin{array}{c}4,74 \\
(2,1-10,8)\end{array}$ & 0,000 & $\begin{array}{c}4,21 \\
(1,9-9,4)\end{array}$ & 0,000 & $\begin{array}{c}4,28 \\
(1,9-9,4)\end{array}$ & 0,000 \\
\hline Asupan karbohidrat & $\begin{array}{c}3,27 \\
(1,2-8,7)\end{array}$ & 0,018 & $\begin{array}{c}4,34 \\
(1,8-10,1)\end{array}$ & 0,001 & $\begin{array}{c}5,23 \\
(2,3-11,7)\end{array}$ & 0,000 & $\begin{array}{c}5,42 \\
(2,4-12,1)\end{array}$ & 0,000 & $\begin{array}{c}4,88 \\
(2,2-10,6)\end{array}$ & 0,000 \\
\hline $\begin{array}{l}\text { Jenis } \\
\text { kelamin }\end{array}$ & $\begin{array}{c}0,41 \\
(0,2-1,0)\end{array}$ & 0,055 & $\begin{array}{c}0,39 \\
(0,2-0,9)\end{array}$ & 0,046 & $\begin{array}{c}0,38 \\
(0,2-0,9)\end{array}$ & 0,044 & $\begin{array}{c}0,43 \\
(0,2-1,1)\end{array}$ & 0,068 & - & - \\
\hline $\begin{array}{l}\text { Aktivitas } \\
\text { olahraga }\end{array}$ & $\begin{array}{c}2,02 \\
(0,9-4,4)\end{array}$ & 0,079 & $\begin{array}{c}2,03 \\
(0,9-4,4)\end{array}$ & 0,075 & $\begin{array}{c}1,98 \\
(0,9-4,3)\end{array}$ & 0,084 & - & - & - & - \\
\hline $\begin{array}{l}\text { Log } \\
\text { likelihood }\end{array}$ & \multicolumn{2}{|c|}{$-89,2215$} & \multicolumn{2}{|c|}{$-89,8257$} & \multicolumn{2}{|c|}{$-91,1846$} & \multicolumn{2}{|c|}{$-92,7156$} & \multicolumn{2}{|c|}{$-94,4271$} \\
\hline $\mathrm{R}^{2}$ & \multicolumn{2}{|c|}{0,3961} & \multicolumn{2}{|c|}{0,3920} & \multicolumn{2}{|c|}{0,3828} & \multicolumn{2}{|c|}{0,3724} & \multicolumn{2}{|c|}{0,3608} \\
\hline
\end{tabular}

Analisis regresi logistik dilakukan dengan menggunakan metode backward stepwise regression. Analisis dimulai dengan memasukkan seluruh variabel yang dianggap penting atau yang memiliki tingkat kemaknaan (p) kurang dari 0,25 ke dalam model, kemudian secara bertahap mengeluarkan variabel-variabel yang memiliki nilai $\mathrm{p}>0,05$ dan dimulai dari variabel dengan nilai $\mathrm{p}$ terbesar. Faktorfaktor yang memiliki hubungan signifikan dengan status gizi adalah tingkat kecemasan, asupan lemak, dan asupan karbohidrat (model 5). Variabel tingkat kecemasan memiliki hubungan yang paling kuat dengan status gizi, ditunjukkan dengan OR yang paling besar (Tabel 6). 


\section{BAHASAN}

Berdasarkan hasil penelitian, dari 214 lansia yang menjadi subjek penelitian ditemukan sebanyak 56 orang (26,2\%) yang mengalami tingkat kecemasan sedang. Prevalensi tingkat kecemasan hampir sama dengan tingkat kecemasan pada lansia di Finlandia dengan 29.133 subjek pria yang berusia 50-69 tahun, yaitu sebesar 24\% (10). Penelitian di enam negara di Eropa pada 21.425 subjek menunjukkan bahwa prevalensi gangguan kecemasan sebesar 13,6\%; laki-laki 9,5\%; dan perempuan 17,5\% (OR=2,43) (24). Prevalensi tingkat kecemasan pada lansia di Kota Yogyakarta lebih rendah dibandingkan dengan prevalensi tingkat kecemasan pada lansia di Kabupaten Purworejo yaitu sebesar 34,92\% (8), lebih rendah juga dibandingkan dengan prevalensi kecemasan pada wanita dewasa dan lansia hasil analisis data dari American Association of retired Person's. Analisis Images Aging Survey yang dilakukan pada tahun 1994 melalui telepon pada 1.200 orang di Amerika menemukan bahwa prevalensi kecemasan wanita usia lanjut sebesar 45,06\% (25).

Kondisi kecemasan pada lansia yang terjadi dapat disebabkan karena perbedaan sosial ekonomi (memasuki masa pensiun), penurunan pendapatan, post power syndrome, konflik peran, dan merasa kurang atau tidak dibutuhkan lagi, kondisi kesehatan sudah mulai menurun dan sering mengalami gangguan fisik, serta penyakit sudah mulai bermunculan. Perbedaan prevalensi tingkat kecemasan ini dapat disebabkan oleh adanya perbedaan karakteristik lingkungan sekitar subjek, yang meliputi faktor budaya atau sosial ekonomi, selain tentunya karena ada perbedaan parameter pengukuran tingkat kecemasan yang digunakan. Di samping itu, dapat disebabkan juga oleh perbedaan penerimaan subjek penelitian terhadap kecemasan yang dialami, sikap yang dapat menerima keadaan dalam kondisi apapun, serta perbedaan faktor budaya antara subjek penelitian yang ada di Kota Yogyakarta dengan yang ada di Kabupaten Purworejo, maupun yang ada di Amerika.

Hasil analisis multivariat menunjukkan bahwa faktor yang paling dominan memengaruhi tingkat kecemasan adalah variabel jenis kelamin. Lansia yang memiliki jenis kelamin perempuan berisiko 3,37 kali lebih besar mengalami tingkat kecemasan sedang dibandingkan dengan lansia laki-laki. Sebesar 67\% lansia perempuan yang mengalami tingkat kecemasan sedang, mengonsumsi lemak dan minyak dan sebesar $83 \%$ mengonsumsi serealia, umbi-umbian, dan hasil olahannya. Hal ini sejalan dengan penelitian yang menyatakan bahwa dalam keadaan stres, pola makan berbeda secara signifikan untuk wanita dan laki-laki. Perempuan lebih cenderung meningkatkan konsumsi makan terutama makanan manis tertentu atau konsumsi lemak dalam respon terhadap stress dibandingkan dengan laki-laki (26). Seorang wanita lebih sering mengalami gejala kecemasan dibandingkan dengan laki-laki (27). Lebih lanjut, penelitian pada 4.320 responden di London Selatan juga mengemukakan bahwa lebih banyak perempuan stres dibandingkan laki-laki $(p<0,01)$ (28).

Hasil analisis menunjukkan adanya hubungan yang signifikan antara tingkat kecemasan dengan status gizi $(\mathrm{p}<0,05)$. Nilai OR sebesar 3,54 menunjukkan bahwa subjek yang mengalami tingkat kecemasan sedang berisiko 3,54 kali lebih besar untuk mengalami status gizi lebih dibandingkan dengan subjek yang mengalami tingkat kecemasan ringan. Sementara nilai OR sebesar 2,29 menunjukkan bahwa subjek yang mengalami tingkat kecemasan sedang memiliki kemungkinan 2,29 kali lebih besar untuk mengalami status gizi kurang dibandingkan dengan subjek yang mengalami tingkat kecemasan ringan. Penelitian ini belum dapat menentukan faktor sebab dan akibat secara jelas karena variabel-variabelnya diukur pada satu waktu yang hampir bersamaan. Namun, hasil penelitian ini secara logika lebih menunjukkan bahwa tingkat kecemasan sedang merupakan salah satu faktor risiko terjadinya status gizi lebih dan status gizi kurang.

Hubungan yang signifikan antara tingkat kecemasan dengan status gizi ini sejalan dengan penelitian sebelumnya yang dilakukan di Turki yang menyatakan bahwa stres yang diukur dengan menggunakan instrumen stress symptom scale, stress related factors, susceptibility to stress scale dan total score berhubungan secara bermakna dengan indeks massa tubuh (IMT), asupan energi, dan zat-zat gizi sehari-hari. Penelitian ini menunjukkan bahwa stres mempunyai peran yang penting pada kejadian underweight dan overweight serta pada energi dan item makanan yang dikonsumsi ( $\mathrm{p}<0,0001)$ (29). 
Pada penelitian ini, hubungan antara tingkat kecemasan sedang dengan asupan makan lebih bermakna secara statistik $(\mathrm{p}<0,001)$, tetapi tidak ada hubungan yang bermakna secara statistik antara tingkat kecemasan sedang dengan asupan makan kurang $(\mathrm{p}>0,05)$. Hal ini menunjukkan bahwa dalam penelitian ini subjek dengan tingkat kecemasan sedang cenderung untuk mengalami asupan makan lebih, terbukti dengan nilai OR pada subjek dengan tingkat kecemasan sedang yang mengalami asupan makan lebih, lebih besar dibandingkan dengan subjek dengan tingkat kecemasan sedang yang memiliki asupan makan kurang. Faktor psikologis seperti depresi, kecemasan, dan demensia mempunyai kontribusi yang besar dalam menentukan asupan makan dan zat gizi lansia (13). Stres diketahui juga dapat menyebabkan gangguan makan, baik berupa nafsu makan berkurang atau meningkat (30). Dalam keadaan tertentu, stres dan tugas beban kerja tinggi, terjadi peningkatan asupan energi, lemak, karbohidrat, dan protein, yang ditunjukkan dengan perbedaan rata-rata asupan energi (31). Kecemasan tinggi menyebabkan konsumsi energi dan lemak jenuh meningkat $(p<0,05)(32)$. Kecemasan juga telah dikaitkan dengan alkohol dan asupan lemak meningkat, termasuk lemak jenuh, omega-6, dan omega-3 (33). Subjek dengan kecemasan tinggi cenderung makan snack manis dan asin berenergi tinggi serta lemak tinggi $(\mathrm{p}<0,01)$, sedangkan subjek dengan kecemasan kurang cenderung memilih buah-buahan dan sayuran, daging, dan ikan (28).

Asupan makan merupakan faktor yang berpengaruh langsung secara linier dalam menentukan status gizi seseorang. Konsumsi makan berpengaruh terhadap status gizi seseorang (21). Jika lansia mengonsumsi lebih dari $3.500 \mathrm{kcal}$ energi, maka kelebihan dari kebutuhan tersebut dapat memproduksi 0,45 kg lemak. Kelebihan 1000 kcal per hari akan menambah $1 \mathrm{~kg}$ timbunan lemak per minggu. Dengan demikian, orang yang makan berlebih secara terus menerus akan mudah mengalami obesitas (6). Seseorang dengan asupan energi tidak cukup, berisiko 3,2 kali lebih besar untuk mengalami kekurangan gizi dibandingkan dengan subjek yang asupan energinya cukup (34). Peningkatan IMT subjek dalam masa satu tahun pengamatan terjadi lebih besar pada subjek yang memiliki rata-rata asupan energi lebih tinggi $(p<0,05)$ (35).
Pada penelitian ini, asupan makan yang meliputi asupan energi, protein, lemak, dan karbohidrat memiliki hubungan yang signifikan dengan status gizi $(\mathrm{p}<0,05)$. Subjek dengan asupan makan yang lebih memiliki kemungkinan lebih tinggi untuk mengalami gizi lebih. Hasil penelitian ini diduga dipengaruhi oleh faktor tingkat kecemasan. Subjek yang tingkat kecemasannya sedang akan cenderung menambah asupan makan sehingga diharapkan akan timbul rasa nyaman.

Pengambilan data asupan makan dan status gizi yang dilakukan pada satu waktu tertentu juga dapat memengaruhi hasil penelitian ini sehingga tidak dapat ditentukan faktor sebab dan akibat secara jelas. Secara logika, hasil penelitian ini lebih menunjukkan bahwa asupan makan merupakan salah satu faktor yang memengaruhi status gizi subjek. Hasil penelitian ini sejalan dengan hasil penelitian di Belgia pada 485 pria dan 362 wanita dewasa. Disimpulkan bahwa pada kelompok berjenis kelamin pria maupun wanita, jumlah asupan energi, protein, dan lemak (kcal/hari) jauh lebih tinggi pada subjek yang obesitas. Persentase asupan energi dari lemak secara signifikan lebih tinggi pada pria obesitas dibandingkan pada pria dengan berat badan dan lingkar pinggang yang normal. Persentase energi dari karbohidrat dan serat secara negatif terkait dengan IMT dan lingkar pinggang pada pria sedangkan pada wanita asupan karbohidrat dan serat tinggi, positif terkait dengan obesitas (36).

Berdasarkan hasil analisis multivariat terhadap beberapa variabel yang diduga berhubungan dengan status gizi, model 5 diketahui bahwa faktor-faktor yang memiliki hubungan signifikan dengan status gizi dalam penelitian ini adalah tingkat kecemasan, asupan lemak, dan asupan karbohidrat. Dari kelima model yang ditampilkan, meskipun nilai $\mathrm{R}^{2}$ terbesar ditunjukkan pada model 1 yaitu 0,3961 , tetapi perbedaannya dengan model 5 tidak terlalu signifikan. Dengan demikian, dalam penelitian ini dipilih model 5 untuk menjelaskan faktor-faktor yang terkait dengan status gizi dengan mempertimbangkan aspek statistik dan substansi. Model tersebut merupakan model yang parsimory, artinya model yang memiliki sedikit variabel namun cukup baik untuk menjelaskan variabel dependent (terikat) (37). Hasil analisis multivariat tersebut juga menunjukkan bahwa 
variabel yang paling dominan berhubungan dengan status gizi pada lansia adalah tingkat kecemasan yang dibuktikan dengan nilai OR yang paling besar.

\section{SIMPULAN DAN SARAN}

Tingkat kecemasan dan status gizi lansia menunjukkan hubungan yang bermakna. Lansia dengan tingkat kecemasan sedang cenderung memiliki status gizi lebih $(\mathrm{OR}=3,54)$ dan status gizi kurang $(\mathrm{OR}=2,29)$. Terdapat hubungan yang bermakna antara tingkat kecemasan sedang dengan asupan makan lebih pada lansia di kota Yogyakarta $(\mathrm{OR}=6,22)$. Demikian juga ditemukan adanya hubungan yang bermakna antara asupan makan dengan status gizi lansia di Kota Yogyakarta. Lansia yang memiliki asupan makan lebih cenderung memiliki status gizi lebih $(\mathrm{OR}=6,15)$.

Berdasarkan simpulan tersebut maka sebaiknya lansia lebih memperhatikan asupan makan, terutama asupan lemak dan karbohidrat sesuai dengan kecukupan tubuh sebagai upaya untuk mendapatkan dan mempertahankan berat badan ideal, serta melakukan aktivitas olahraga secara teratur minimal $3 \mathrm{kali} /$ minggu sebagai upaya untuk mengurangi tingkat kecemasan sedang. Bagi peneliti selanjutnya, perlu dipertimbangkan penggunaan alat ukur tingkat kecemasan yang tepat untuk lansia dan penggalian data asupan makan melalui metode SQ-FFQ dengan didukung metode lain misalnya food record sehingga lebih bisa meminimalisir terjadinya bias informasi.

\section{RUJUKAN}

1. BPS (Badan Pusat Statistik). Statistik penduduk lanjut usia, 2009. Jakarta: BPS; 2010.

2. Dinas Kesehatan Provinsi DIY. Profil kesehatan provinsi D.I Yogyakarta tahun 2009. Yogyakarta: Dinkes DIY; 2010.

3. BPS Provinsi DIY. Daerah Istimewa Yogyakarta dalam angka 2010. Yogyakarta: BPS DIY; 2010.

4. BPS Kota Yogyakarta. Kota Yogyakarta dalam angka. Yogyakarta: BPS Kota Yogyakarta; 2010.

5. Martono H. Gangguan kesadaran dan kognitif pada usia lanjut (konfusio akut dan dementia). Dalam: Martono H, Pranaka K. Buku ajar Boedhi-Darmojo geriatri (ilmu kesehatan usia lanjut). Jakarta: Balai Penerbit FKUI; 2010 .
6. Fatmah. Gizi usia lanjut. Jakarta: Erlangga; 2010.

7. Nugroho HW. Keperawatan gerontik \& geriatrik. Jakarta: EGC; 2012.

8. Hastuti L, Hakimi M, Dasuki D. Hubungan antara kecemasan dengan aktifitas dan fungsi seksual pada wanita usia lanjut di Kabupaten Purworejo. Berita Kedokteran Masyarakat 2008;24(4):176-90.

9. Macdonald AJD. Kesehatan mental pada lanjut usia. Dalam: Davies T, Craig T. editor. ABC Kesehatan Mental. Jakarta: EGC; 2009.

10. Hakkarainen R, Partonen T, Haukka J, Virtamo J, Albanes $\mathrm{D}$, Lonnqvist J. Food and nutrient intake in relation to mental wellbeing. Nutr J 2004;3:14.

11. Kaplan HI, Sadock BJ. Comprehensive Textbook of Psychiatry/VI. Philadelphia: Lippincott Williams \& Wilkins; 1995.

12. Blackburn M, Davidson KM. Cognitive therapy for depression \& anxiety. Boston Melbourne: Blackwell Scientific Publication; 1994.

13. Fatimah-Muis S, Puruhita N. Gizi pada lansia. Dalam: Martono H, Pranaka K. Buku ajar Boedhi-Darmojo: geriatri (ilmu kesehatan usia lanjut). Jakarta: Balai Penerbit FKUI; 2010.

14. Kubzansky LD, Kawachi I, Weiss ST, Sparrow D. Anxiety and coronary heart disease: a synthesis of epidemiological, psychological, and experimental evidence. Ann Behav Med 1998; 20(2):47-58.

15. Roest AM, Martens EJ, Jonge P, Denollet J. Anxiety and risk of incident coronary heart disease: a meta-analysis. JACC 2010;56(1):38-46.

16. Riyadi A, Wiyono P, Budiningsari RD. Asupan zat gizi dan status gizi sebagai faktor risiko hipertensi esensial pada lansia di Puskesmas Curup dan Perumnas Kabupaten Rejang Lebong Propinsi Bengkulu. Jurnal Gizi Klinik Indonesia 2007;4(1):43-51.

17. Surilena, Agus D. Faktor-faktor yang memengaruhi depresi pada lansia di Jakarta. Majalah Kedokteran Damianus 2006;5(2):115-29.

18. Marliyati SA, Kustiyah L, Madanijah S. Kesehatan dan gizi di usia emas. Bogor: Departemen Gizi Masyarakat Fakultas Ekologi Manusia IPB; 2008.

19. Morley JE, Silver AJ. Nutritional issues in nursing home care. Ann Intern Med 1995;123:850-59.

20. Enny E, Elnovriza D, Hamid S. Faktor-faktor yang berhubungan dengan status gizi usila di Kota Padang tahun 2006. Jurnal Kesehatan Masyarakat 2006;1(1):5-8.

21. Saniawan IM. Status gizi pada lanjut usia pada Banjar Paang Tebel di Desa Peguyangan Kaja Wilayah Kerja Puskesmas III Denpasar Utara. Jurnal Ilmiah Keperawatan 2009;2(1):45-9. 
22. Lemeshow S, Hosmer DWJr, Klar J, Lwanga SK. Besar sampel dalam penelitian kesehatan. Pramono D (Alih bahasa). Yogyakarta: Gadjah Mada University Press; 1997.

23. Rabe B, Thamrin MH, Gross R, Solomons NW, Schultink W. Body mass index of the elderly derived from height and from armspan. Asia Pac J Clin Nutr 1996;5:79-83.

24. Alonso J, Angermeyer MC, Bernert S, Bruffaerts R, Brugha TS, Bryson H. Prevalence of mental disorders in Europe: Results from the European study of the epidemiology of mental disorders (ESEMeD) project. Acta Psychiatrica Scandinavica. Supplementum 2004;21-7.

25. Lynch SM. Measurement and prediction of aging anxiety, Research on aging. Sage Publications 2000;22(5):53358.

26. Zellner DA, Loaiza S, Gonzalez Z, Pita J, Morales J, Pecora D, WolfA. Food selection changes under stress. Physiology \& Behavior 2006;87:789-93.

27. Merikangas KR, Pollock RA. Anxiety disorders in women. Women \& Health 2000;1010-23.

28. Cartwright M, Wardle J, Steggles N, Simon AE, Croker $\mathrm{H}$, Jarvis MJ. Stress and dietary practices in adolescents. Health Psychol 2003;22(4):362-9.

29. Sanlier N, Unusan N. The relationship between body weight and stress and nutritional status in Turkish women. Pak J Nutr 2007;6(4):339-44.

30. Tirta M, Wirasto RT, Huriyati E. Status stres psikososial dan hubungannya dengan status gizi siswa SMP Stella
Duce 1 Yogyakarta. Jurnal Gizi Klinik Indonesia 2010;6(3):138-44.

31. Chaput JP, Tremblay A. Acute effects of knowledge-based work on feeding behavior and energy intake. Physiology \& Behavior 2007;90:66-72.

32. Pollard TM, Steptoe A, Canaan L, Davies GJ, Wardle J. Effects of academic examination stress on eating behavior and blood lipid levels. Int J Behav Med 1995;2(4):299320.

33. Hakkarainen R, Partonen T, Haukka J, Virtamo J, Albanes $\mathrm{D}$, Lonnqvist J. Food and nutrient intake in relation to mental wellbeing. Nutr J 2004;3:14.

34. Dwiyanti D, Hadi H, Susetyowati. Pengaruh asupan makanan terhadap kejadian malnutrisi di rumah sakit. Jurnal Gizi Klinik Indonesia 2004;1(1):1-7.

35. Berkey CS, Rockett HRH, Field AE, Gillman MW, Fraizer AL, Camargo JrCA, Colditz GA. Activity, dietary intake, and weight changes in a longitudinal study of preadolescent and adolescent boys and girls. Pediatrics 2000;105(4):1-9.

36. Duvigneaud N, Wijndaele K, Matton L, Philippaerts R, Lefevre J, Thomis M, Delecluse C, Duquet W. Dietary factors associated with obesity indicators and level of sport participation in Flemish adults: a cross-sectional study. Nutr J 2007;6(26):1-12.

37. Riyanto A. Penerapan analisis multivariat dalam penelitian kesehatan. Yogyakarta: Nuha Medika; 2012. 